\title{
Analysis of public search interest towards immune system improvement during the COVID-19 pandemic using Google Trends
}

\author{
Linda Amelia ${ }^{1}$, Rizma Adlia Syakurah ${ }^{2}$ \\ ${ }^{1}$ Medical Faculty, Sriwijaya University, Indonesia \\ ${ }^{2}$ Public Health Faculty, Sriwijaya University, Indonesia
}

\section{Article Info}

Article history:

Received Jun 12, 2020

Revised Aug 20, 2020

Accepted Sep 11, 2020

Keywords:

COVID-19

Immune System

Risk communication

Sunbathing

Vaccine

Vitamin C

\begin{abstract}
In combating COVID-19, maintaining the immune system is important. Providing this information to the general population will increase public awareness towards improving their immune system. The use of Google Trends for exploring web behavior related to a topic or search term also considered as a tool for monitoring public awareness to help risk communication during the COVID-19 pandemic. Therefore, this study was conducted to assess the use of Google Trends to monitor public awareness to immune system improvement during the COVID-19 pandemic in Indonesia. This quantitative and qualitative research used time-series data from 31 December 2019 to 2 May 2020. The time-lag correlation analysis was performed to compare between relative search volume (RSV) of "Vitamin C", "Vaksin" (Vaccine), "Berjemur" (Sunbathing) from Google Trends (GT), and the number of reported COVID-19 new cases. Validation using time-lag correlation shows the significant correlation between RSV keywords related to public awareness towards immune system improvement and the number of COVID-19 cases in Indonesia in 1-3 days before an increase in the number of cases occurs. Google Trends has the potential to become an early warning system and a tool for monitoring risk communication towards immune system improvement during the COVID-19 pandemic by Indonesia Government.
\end{abstract}

This is an open access article under the CC BY-SA license.

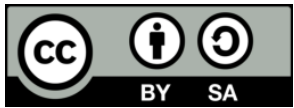

\section{Corresponding Author:}

Rizma Adlia Syakurah,

Public Health Faculty,

Sriwijaya University,

Jl. Raya Palembang-Prabumulih KM. 32 Indralaya, Ogan Ilir, Sumatera Selatan, 30662, Indonesia.

Email: rizma.syakurah@gmail.com

\section{INTRODUCTION}

The Coronavirus 2019 (COVID-19) outbreak was first discovered in the city of Wuhan, China, on 31 December 2019, and quickly spread to other cities in China within days [1, 2]. On 30 January 2020, WHO announced COVID-19 as a public health emergency of international concern [3]. With a high virulence and high proportion of asymptomatic cases, the COVID-19 outbreak quickly spread throughout the world with confirmed cases reached 118.319 (4.620) and mortality reached 4.292 as of 11 March 2020. Thus, WHO categorized COVID-19 as a pandemic [2,4]. COVID-19 is growing rapidly in the world, including in Indonesia with confirmed cases reached 12.438 (632) and mortality reached 895 (8) as of 6 May 2020, case fatality rate (CFR) was $7.2 \%$, higher than worldwide $(6.9 \%)[5,6]$. 
Immunity is the ability of the human body to tolerate the presence of indigenous material to the body (self) and eliminate foreign (nonself) material. This discriminatory ability provides protection from the infectious disease since most microbes are identified as foreign bodies by the immune system. Immunity to a microbe is usually indicated by the presence of antibody to that organism. Immunity is generally specific to a single organism or group of closely related organisms. There are two basic mechanisms for acquiring immunity, active and passive. Active immunity is protection produced by the person's immune system [7]. In combating COVID-19, maintaining the immune system is important. Several things can increase self-immunity in people who are exposed to COVID-19, such as consumption of balanced nutrition, physical activity/mild exercise, adequate rest, vitamin supplements, not smoking, and controlling comorbidities (eg diabetes mellitus, hypertension, cancer) [8]. People should also pay attention to basic health habits like balanced diets, working out, and having enough sleep because it increases the body's immunity [9]. Another way to acquire active immunity is by vaccination. Vaccines help develop immunity by imitating an infection. Vaccines interact with the immune system and often produce an immune response similar to that produced by the natural infection. Many vaccines also produce immunologic memory similar to that acquired by having natural disease. Once the imitation infection goes away, the body is left with a supply of "memory" T-lymphocytes, as well as B-lymphocytes that will remember how to fight that disease in the future. The more similar a vaccine is to the disease-causing form of the organism, the better the immune response to the vaccine [7].

The immune response plays an important role in protecting against infectious agents. It is a well-known fact that for almost all infectious diseases, the number of people exposed to infections is much higher than those who suffer from the disease. This shows that most people can destroy these microorganisms and thus prevent the development of infections. Providing this information to the general population will increase public awareness towards improving their immune system [10].

Risk communication is used to see the dissemination of information to the public regarding health, risks, and events, such as disease outbreaks and instructions on how to change behavior to reduce the impact [11]. Effective risk communication is essential for improving public understanding of potential or actual health threats and helps the public to make informed decisions about risk mitigation measures [12]. Therefore, during a new pandemic, getting information from various sources, such as public health professionals, the government, and the media, can increase people's awareness about the risk, and consequently, their adoption of preventive measures [13].

The internet is increasingly used as a source of health care information. Google Trends is an online tracking system of Internet search volumes that since 2004 is used to explore web behavior related to a topic or search term. GT allows a user to compare up to five terms or topics simultaneously and results are displayed as a set of time series. Google Trends normalizes the search data with the day on which more searches were made giving a reference value equal to 100; on the contrary, it assigns a reference value of 0 for the day when fewer searches were carried out. Then the standardized data are presented by Google Trends as relative search volume (RSV), an Interest Index that can take a value from 0-100 based on the proportion to all searches on all terms or topics.

Infodemiology and infoveillance are essential public health informatics methods which are used to analyze search behavior on the internet. Infodemiology and infoveillance of epidemiological data are important to increase situational awareness and make suitable interventions. The analysis of RSV gives information on the extent of public attention with Google Trends being one of the most widely used tools for this purpose. RSV is used for real-time analyses for transmissibility, severity, and natural history of an emerging pathogen, as observed with the severe acute respiratory syndrome (SARS), the 2009 influenza pandemic, and Ebola. A linear time-series pattern with official dengue reports is indicating a potential use to monitor public interest before an increase of cases and during the outbreak $[2,14]$. This study aims to assess public interest to an increase in the immune system during COVID-19 pandemic by Google Trends, so that it has the potential to become an early warning system and a tool for monitoring public awareness that can be used to help risk communication by Indonesia government.

\section{RESEARCH METHOD}

Data collected used time-series data from 31 December 2019 to 2 May 2020 by Google trends (https://trends.google.com/trends) with related keyword such as "Vitamin C" (Vitamin C), "Vaksin" (Vaccine), and "Berjemur" (Sunbathing) that represented the information search for public awareness during COVID-19 pandemic in Indonesia to improve the immune system. Google trends number represents the relative search volume (RSV) to the highest point for the selected region and time. A value of 100 is the peak popularity of the term, whilst a value of 0 means that the lowest popularity of the term. Every related spike found will be analyzed qualitatively trough GT data then compared with the number of daily COVID-19 new 
cases reported from (http://bnpb-inacovid19.hub.arcgis.com/) as the official website of the task force the acceleration of handling COVID-19 in Indonesia (Gugus Tugas Percepatan Penanganan COVID-19) by the National disaster management agency (Badan Nasional Penanggulangan Bencana/BNPB). Time-lagged correlation in the three-day interval of the number of COVID-19 daily new cases and GT data was analyzed using Pearson Correlation with significance $\leq 0.05$ with level of strength of the corellation (R-value) from 0- 0.2 (very low), 0.21-0.40 (low), 0.40-0.60 (middle), 0.61-0.80 (strong), and 0.80-1 (very strong), to assess between the correlation of the increase of GT data and the increase of Covid-19 cases, as previously applied in other studies [15].

\section{RESULTS AND DISCUSSION}

Table 1 shows the queries of search interests with keywords related to public awareness towards immune system improvement during COVID-19 pandemic in Indonesia. It was found that the keyword "Vitamin $C^{\prime \prime}$ is related to how to get vitamin $\mathrm{C}$ on the markets related to immunity, both in the form of supplements, food, or fruits. Likewise, the keyword "Berjemur" which related to the good time for sunbathing and the benefits of it related to Corona. This shows that people's attention to vitamin $\mathrm{C}$ and sunbathing was focused on how to get it during the COVID-19 pandemic. While the query for the keyword "Vaksin" is directly related to the keywords "corona" and "COVID". This showed that people are directly aware of the "vaksin" with the COVID-19 incident. Table 2 shows the distribution of provinces with the highest interest keywords related to public awareness towards immune system improvement during COVID-19 pandemic in Indonesia. Figure 1 shows an analysis of data from Google Trends with the number of new cases of COVID-19 in Indonesia from the period 31 December 2019 - 2 May 2020. Based on search terms from Google Trends, there were three peaks on the keyword "Vitamin C", three peaks on the keywords "Vaccine", and two peaks in the keywords "Sunbathing".

Table 1. Queries of search interests with keywords related to public awareness towards immune system improvement during COVID-19 pandemic in Indonesia

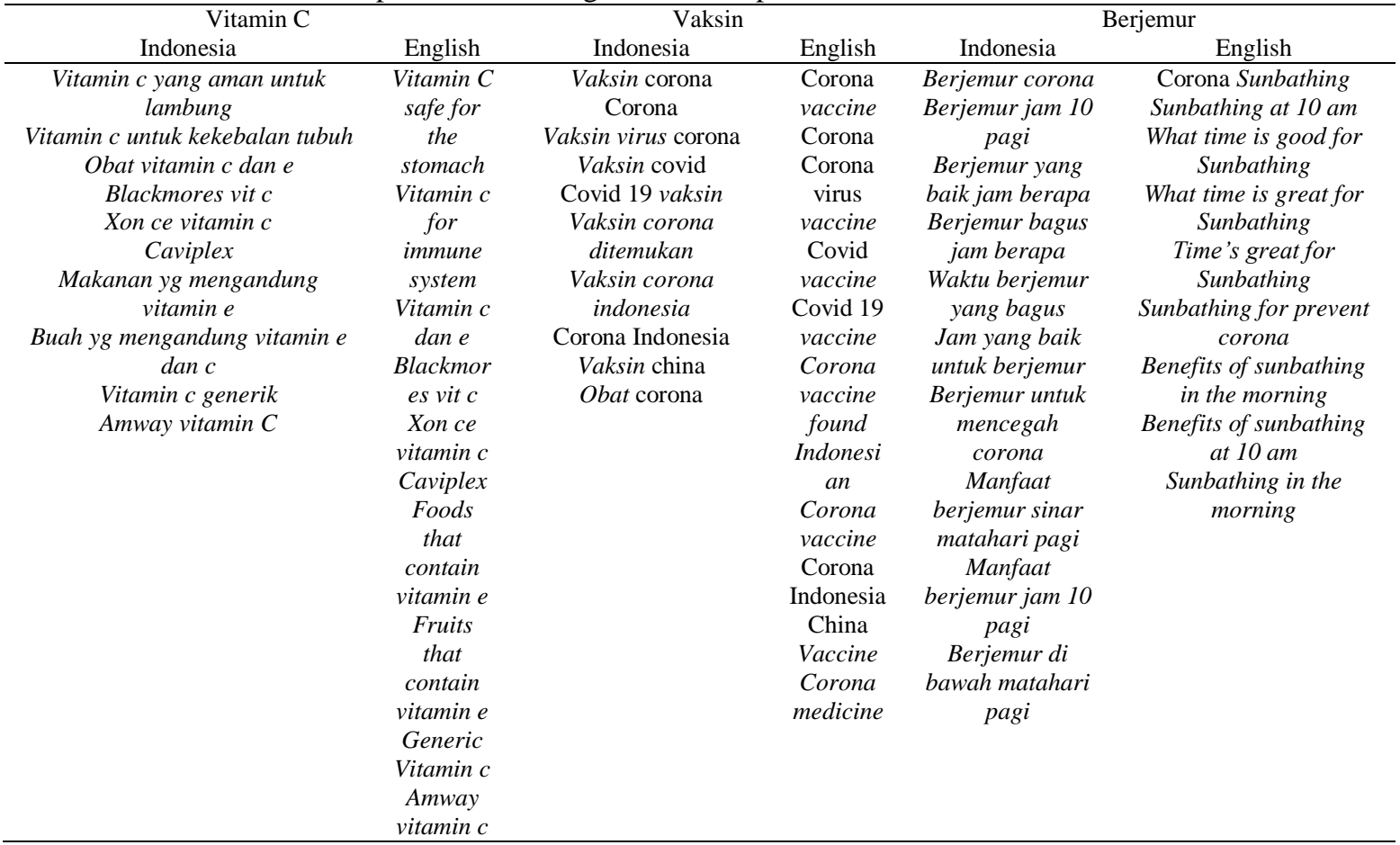

The search pattern of Vitamin C using the keyword "Vitamin C" in Indonesia is quite volatile. There were three peaks in the search term for Vitamin C in Indonesia. Since the first COVID-19 case reported in Wuhan, China, on 31 December 2020, the trend of searching for the keyword "Vitamin C" in Indonesia has been relatively balanced until 1 March 2020, although on 30 January 2020, the WHO announced COVID-19 as a public health emergency of international concern. Then the search trend for 
the keyword "Vitamin C" reached its first peak on 2 March 2020 coincided with the announcement from the government which stated that there were 2 people who infected by the coronavirus as the first case of COVID-19 in Indonesia [16]. News about Vitamin C to protect the body's immunity as well began to appear in Indonesian television and online media. This increase did not last long and gradually declined, although on 11 March 2020 WHO categorized COVID-19 as pandemic and 27 confirmed cases of COVID-19 in Indonesia [4].

Table 2. Provinces with the highest interest keywords related to public awareness towards immune system improvement during COVID-19 pandemic in Indonesia

\begin{tabular}{ccc}
\hline Vitamin C & Vaksin & Berjemur \\
\hline Riau Islands & East Nusa Tenggara & Central Java \\
Gorontalo & North Kalimantan & West Java \\
West Kalimantan & West Papua & Special Region of Yogyakarta \\
West Sulawesi & South Sulawesi & Bengkulu \\
North Kalimantan & West Sulawesi & South Kalimantan \\
Jambi & Bengkulu & Lampung \\
Aceh & Bangka Belitung Islands & Central Kalimantan \\
North Sumatra & West Kalimantan & West Sumatra \\
Banten & Special Region of Yogyakarta & Banten \\
South East Sulawesi & North Sulawesi & Bali \\
\hline
\end{tabular}

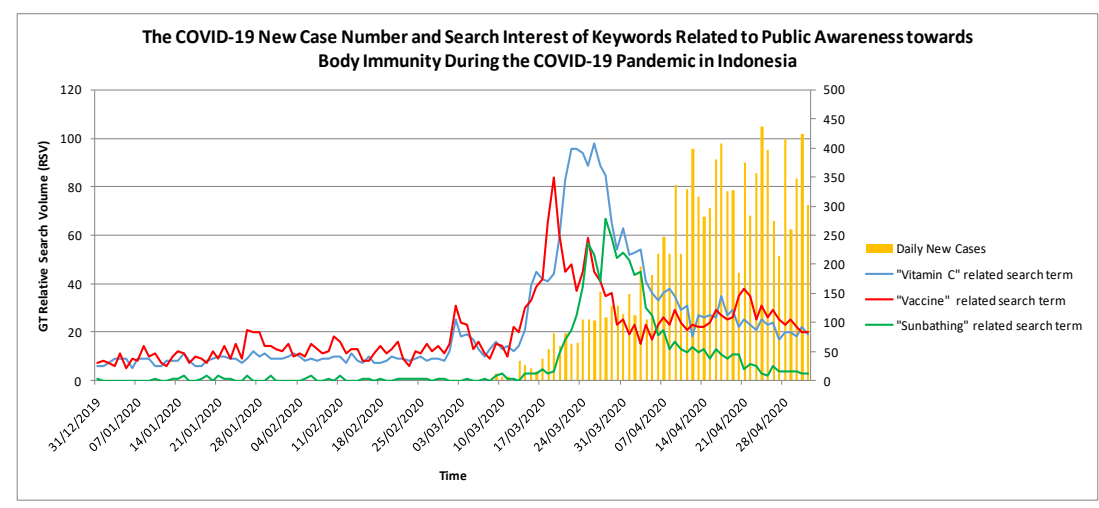

Figure 1. Comparative Indonesia GT RSV and public awareness towards immune system improvement with newly confirmed COVID-19 cases in Indonesia

The second peak occurred on 16 March 2020, when the Government announced the increase of COVID-19 confirmed cases in Indonesia was 134 cases with 17 new cases originating from West Java (1), Banten (1), Central Java (1), and DKI Jakarta (14) [17]. Also, the Government through the Agency National Disaster Management (BNPB) announced an extension of the emergency period of the COVID-19 outbreak in Indonesia until 29 May 2020 and issued a Ministry of Education and Culture Circular as a Government policy regarding online learning and working from home [18-19].

The third peak rose sharply on 20 March 2020 with the number of confirmed cases reached 369 and 32 people died. Coinciding with the press statement of the president of the Republic of Indonesia about the latest information of COVID-19 mitigation and prevention measures, such as the rapid test and the preparation of millions of drugs in the form of five thousand Avigan (Favipiravir) and three million Chloroquine. The Government also called on Indonesian people to maintain their immunity to remain healthy.

In addition, on social media and online news media also circulated news about the treatment of a well-known figure who was positive COVID-19 whose condition improved by consuming several vitamins such as vitamin $\mathrm{C}$ which help the immune system can become stronger. All of these things can affect the public awareness of Indonesian people. This was in line with online news that stated there was an increase in sales of Vitamin C in many pharmacies in Indonesia because many people were flocking to buy Vitamin C to maintain their body's immunity. Google trends data related to Vitamin C remained high from 20-27 March 2020 and began to decline on 28 March 2020. It was also in line with the widespread news about Vitamin C which can help maintain the body's immunity which continued until 27 March 2020 in the online news media and later gradually decreased and stabilized [20-22]. 
The first peak of the search keyword "Vaccine" and "Vitamin C" in Indonesia has a search volume that not much different. The first vaccine-related peak also occurred on 2 March 2020 related to the finding of the first case of COVID-19 and then began to decline thereafter. The second peak occurred on 19 March 2020, with an increasing trend occurring since 16 March 2020 and subsequently declined sharply on 20 March 2020 to 24 March 2020. Chronologically, on 16 March 2020, coincided with the extension of the emergency period of the outbreak of the COVID-19 in Indonesia to 29 May 2020 and issued a Ministry of Education and Culture Circular as a government policy regarding online learning and working from home. On 18 March 2020, the government launched the official COVID-19 website and on 19 March 2020 the number of COVID-19 confirmed cases was 309 with 25 deaths. The president also instructed a special rapid test for early detection of COVID-19. It is coinciding with the news circulating in online media about the development of the corona vaccine in several countries, such as the United States, China, Russia, Saudi Arabia, and so on.

The third peak on 25 March 2020 happened with an online news media report that the Government assigned the Eijkman molecular biology institute (LBME) to lead a consortium to make an anti-COVID-19 vaccine in Indonesia. Vaccine-related searches then gradually declined and were relatively stable until 2 May 2020. Until now the COVID-19 vaccine is still in developmental stages in various countries. WHO is coordinating efforts to develop vaccines and medicines to prevent and treat COVID-19 and will continue to provide updated information as soon as research results become available [23-26].

From 31 December 2019 to 5 March 2020 searches related to sunbathing in Indonesia were the lowest compared to searches related to vitamin $C$ and Vaccines. In Figure 1, a slight increase of searches related to sunbathing began on 6-10 March 2020, then decreased and increased slightly on 15-21 March 2020, then experienced a sharp increase until the peak on 25 March 2020. Also, on 25 March 2020, 105 new cases were recorded so that the number of confirmed cases became 790 cases, with 58 deaths. Online news media in Indonesia was enlivened by a request for sunbathing which also provided information on how to sunbathe well and clarified that sunbathing did not kill the coronavirus but to protect the body's immunity. WHO says exposing to the sun or temperatures higher than 25C degrees does not prevent from COVID-19. Government officials or employees carry out sunbathing in the morning to maintain body immunity and encourage the public to sunbathe while maintaining physical distancing. Similarly, on social media, that is enlivened by well-known figures in Indonesia to engage the public to sunbathe. The second peak occurred on 28 March 2020, where online coverage related to sunbathing continued to increase, as government officials held meetings in the open space while sunbathing to increase body immunity. Then searches related to sunbathing gradually decreased and became relatively stable [27-29].

As seen in Table 3, validation using Pearson correlation shows a significant correlation (p-value $\leq 0.05$ ) with low positive correlation (R-value .20 to .40) between Google Trends data related to Vitamin C, vaccines, and sunbathing and COVID-19 new cases in Indonesia. The correlation of the keyword "Vaksin" is higher than the keyword "Vitamin C" and "Berjemur" with values of 0.3701, 0.3036 , and 0.2957 , respectively.

Table 3. Time-lag Pearson correlations between the keywords in GT RSV and COVID-19 daily cases in Indonesia

\begin{tabular}{lccccccc}
\hline \multirow{2}{*}{ Search Term } & \multicolumn{7}{c}{ Days } \\
& -3 & -2 & -1 & 0 & +1 & +2 & +3 \\
\hline "Vitamin C" & $0.3724^{*}$ & $0.3469^{*}$ & $0.3203^{*}$ & $0.3036^{*}$ & $0.2855^{*}$ & $0.2756^{*}$ & $0.2531^{*}$ \\
"Vaksin" & $0.4134^{*}$ & $0.4054^{*}$ & $0.3876^{*}$ & $0.3701^{*}$ & $0.3580^{*}$ & $0.3334^{*}$ & $0.3346^{*}$ \\
"Berjemur" & $0.3748^{*}$ & $0.3554^{*}$ & $0.3201^{*}$ & $0.2957^{*}$ & $0.2841^{*}$ & $0.2755^{*}$ & $0.2582^{*}$ \\
\hline
\end{tabular}

*Pearson correlation significant at $p \leq 0.05$

\begin{tabular}{|l|l|l|l|l|}
\hline $0-0.2$ & $0.21-0.40$ & $0.40-0.60$ & $0.61-0.80$ & $0.80-1$ \\
\hline
\end{tabular}

Pearson correlation coefficient

Time lag correlation results show a low positive correlation between COVID-19 case reports and Google Trends data 1-3 days before, with R-values in the range 0.3203-0.3724 for the keyword "Vitamin C", 0.3876-0.4134 for the keyword "Vaksin", and 0.32014-0.3748 for the keyword "Berjemur". The search for information using the keyword "Vaksin" in the previous three days showed the highest correlation with COVID-19 case reports. These results indicate that the increased search activity via Google regarding Vitamin $\mathrm{C}$, vaccines and sunbathing occurred three days before, when they occurred, and three days after the increase of COVID-19 new cases in Indonesia.

These results indicate that GT can be used as a tool to monitor public awareness of the COVID-19 outbreak in Indonesia in 1-3 days before and after an increase in the number of cases occurs. Improvements 
in analyzing public awareness when an outbreak occurs primarily can help maximize the risk communication undertaken by the government to change people's behavior [2]. Risk communication helps to improve the communication of risk information and improve the effectiveness and efficiency of multi-sectoral collaboration and therefore can be an ideal tool for experts and the public to improve the management of public health events [30]. Engaging with the media is an important but challenging task. The internet and social media pose the potential for the spread of unsubstantiated rumors about health risks but also new opportunities for communicating health messages. Rapidly evolving knowledge about the epidemiology of the disease and its impact required ongoing communication with all involved groups. Key tasks for public health professionals are: to ensure the dissemination of key messages about disease control; to ensure the media are regularly updated, and to acknowledge uncertainty. They also have to understand the concerns of the public and respond accordingly. These efforts help to maintain the confidence and trust of the public and ultimately, lead to the relevance and effectiveness of public health messages [12]. To controlling the hoax, the government is expected to do a one-door risk communication based on public interest in searching the internet. WHO stated that the result of risk communication should be measured, that is important to reduce the impact therefore risk communication should be properly [11].

\section{CONCLUSION}

Based on Google Trends data, searches related to public awareness towards immune system improvement during COVID-19 pandemic in Indonesia are very volatile and depend on the Government reports, news or social media. This shows that the search process has not yet originated from the will or behavior of the people. Google Trends can be used as a tool to monitor public awareness of the COVID-19 outbreak in Indonesia in 1-3 days before an increase in the number of cases occurs and also establishes the appropriate location and time for risk communication which allows the medical professionals and the Government to provide the health promotion and prevention. We encourage them to use the internet (the news or social media) as a means of communication to deliver health messages to the public by always updating the information regularly and preventing the spread of false rumors related to COVID-19, while continuing to urge the public to prevent infection by washing hands, keeping a distance, and doing ethical cough so that expected to reduce the number of COVID-19 cases in Indonesia.

\section{REFERENCES}

[1] World Health Organization, "Coronavirus disease (COVID-19) situation report -1", World Health Organization, 21 January 2020. [Online]. Available: https://www.who.int/docs/default-source/coronaviruse/situationreports/20200121-sitrep-1-2019-ncov.pdf?sfvrsn=20a99c10_4

[2] Effenberger, M., et al., "Association of the COVID-19 pandemic with Internet Search Volumes: A Google TrendsTM Analysis” International Journal of Infectious Diseases, vol. 95, pp. 192-197, 2020.

[3] World Health Organization, "Coronavirus disease (COVID-19) situation report-10", World Health Organization, 30 January 2020. [Online]. Available: https://www.who.int/docs/default-source/coronaviruse/situationreports/20200130-sitrep-10-ncov.pdf?sfvrsn=d0b2e480_2

[4] World Health Organization, "Coronavirus disease (COVID-19) situation report-51", World Health Organization, 11 March 2020. [Online]. Available: https://www.who.int/docs/default-source/coronaviruse/situationreports/20200311-sitrep-51-covid19.pdf?sfvrsn=1ba62e57_10

[5] World Health Organization, "Coronavirus disease (COVID-19) situation report-107", World Health Organization, 6 May 2020. [Online]. Available from: https://www.who.int/docs/default-source/coronaviruse/situationreports/20200506COVID-19-sitrep-107.pdf?sfvrsn=159c3dc_2

[6] Kementerian Kesehatan Republik Indonesia, "Ministry of Health's Emerging Infection Info (Info Infeksi Emerging Kementerian Kesehatan RI)", Kementerian Kesehatan Republik Indonesia, 7 May 2020. [Online]. Available: https://covid19.kemkes.go.id/

[7] CDC, Principle of Vaccination, Centers for Disease Control and Pevention, cited 2020 May 7. [Online]. Available from: https: //www.cdc.gov/vaccines/pubs/pinkbook/downloads/prinvac.pdf.

[8] Kementerian Kesehatan Republik Indonesia, "Pedoman Pencegahan dan Pengendalian Coronavirus Disease (COVID-19) Revisi Ke-4,” Kementerian Kesehatan Republik Indonesia, 7 May 2020. [Online]. Available: https: //covid19.kemkes.go.id/downloads/?dl_cat=7\#.XrlZxGhKjIV

[9] Mohammed, AS., et al., "Public Awareness about Corona Virus for KAMC Visitors in Riyadh," Jacobs Journal of Community Medicine, vol. 2, no. 1, p. 017, 2016.

[10] Paulo R.L., et al., "Immune response mechanisms to infections. An. Bras. Dermatol," Rio de Janeiro., vol. 79, no. 6, pp. 647-664, 2004.

[11] World Health Organization, "21st century challenges and opportunities for risk communications," ESSACHES J Commun Stud., vol. 5, pp. 1-9, 2012.

[12] Chris P.L.A., Julie L., "Risk communication in public health," NSW Public Health Bulletin., vol. 22, pp. 1-2, 2011.

[13] Mohsen Khosravi, "Perceived Risk of COVID-19 Pandemic: The Role of Public Worry and Trust," Electronic Journal of General Medicine, vol. 17, no. 4, pp. 1-2, 2020. 
[14] Santangelo O.E., et al., "Digital epidemiology: assessment of measles infection through Google Trends mechanism in Italy," Ann Ig., vol. 31, no. 4, pp. 385-391, 2019.

[15] Husnayain A., Fuad A., Su EC., "Applications of google search trends for risk communication in infectious disease management: A case study of COVID-19 outbreak in Taiwan," International Journal of Infectious Diseases, vol. 95 , pp. 221-223, 2020.

[16] Ihsanuddin, Breaking News: Jokowi Announces Two People in Indonesia are Positive Corona (Breaking News: Jokowi Umumkan Dua Orang di Indonesia Positif Corona, Kompas, 02 Maret 2020. [Online]. Available: https://nasional.kompas.com/read/2020/03/02/11265921/breaking-news-jokowi-umumkan-dua-orang-di-indonesiapositif-corona?page $=1$

[17] Acmad Yurianto, "As of March 16, a total of 134 Positive People with COVID-19 and 3 Patients were Discharged (Per 16 Maret Total 134 Orang Positif COVID-19 dan 3 Pasien Dipulangkan)," Kementrian Kesehatan Republik Indonesia, 16 Maret 2020. [Online]. Available from: https://setkab.go.id/acmad-yurianto-per-16-maret-total-134orang-positif-COVID-19-dan-3-pasien-dipulangkan/

[18] Kominfo, "Prevent the Spread of COVID-19 by Working at Home for ASN (Cegah Penyebaran COVID-19 dengan Kerja di Rumah bagi ASN)," Kementrian Komunikasi dan Informatika, 16 Maret 2020. [Online]. Available: https://www.kominfo.go.id/content/detail/25083/cegah-penyebaran-COVID-19-dengan-kerja-di-rumah-bagi asn/0/berita

[19] Koesmawardhani N.W., Government Sets Corona Disaster Emergency Period until May 29, 2020 (Pemerintah Tetapkan Masa Darurat Bencana Corona hingga 29 Mei 2020), 16 Maret 2020. [Online]. Available https://news.detik.com/berita/d-4942327/pemerintah-tetapkan-masa-darurat-bencana-corona-hingga-29-mei-2020

[20] Kominfo, "Press Statement of the President of the Republic of Indonesia on Current Information of COVID-19 Mitigation and Preventive Measures," Kementrian Komunikasi dan Informatika, 21 Maret 2020. [Online]. Available:https://kominfo.go.id/content/detail/25271/press-statement-of-the-president-of-the-republic-of-indonesiaon-current-information-of-COVID-19-mitigation-and-preventive-measures/0/virus_corona

[21] Sari RP, Positive Corona, Olga Kurylenko Drinks Only Paracetamol and Vitamins, The Result (Positif Corona, Olga Kurylenko Hanya Minum Paracetamol dan Vitamin, Hasilnya), Kompas, 20 Maret 2020. [Online]. Available: https://www.kompas.com/hype/read/2020/03/20/082346766/positif-corona-olga-kurylenko-hanya-minumparacetamol-dan-vitamin-hasilnya

[22] Wijayanto, Many Hunted Multivitamins, Pharmaceutical Industry Performance Increases 10 Percent Multivitamin (Banyak Diburu, Kinerja Industri Farmasi Naik 10 Persen), Jawapos, 20 Maret 2020. [Online]. Available: https://radarsurabaya.jawapos.com/read/2020/03/20/184817/multivitamin-banyak-diburu-kinerja-industri-farmasinaik-10-persen

[23] Kominfo, "BNPB Extends Emergency Status for COVID-19 Until May 29, 2020 (BNPB Perpanjang Status Darurat COVID-19 Hingga 29 Mei 2020)," Kementrian Kesehatan Republik Indonesia, 17 Maret 2020. [Online]. Available: https://www.kominfo.go.id/content/detail/25140/bnpb-perpanjang-status-darurat-COVID-19-hingga-29mei-2020/0/berita

[24] Kominfo, "Government Launches Official Website for COVID-19 (Pemerintah Luncurkan Situs Resmi COVID19)," Kementrian Kesehatan Republik Indonesia, 18 Maret 2020. [Online]. Available: https://www.kominfo.go.id/content/detail/25170/pemerintah-luncurkan-situs-resmi-COVID-19/0/berita

[25] Mukaromah VF., Susul AS., China Develops 9 Potential Vaccines to Fight Corona Virus (China Kembangkan 9 Vaksin Potensial untuk Lawan Virus Corona), Kompas, 18 Maret 2020. [Online]. Available: https://www.kompas.com/tren/read/2020/03/18/133000465/susul-as-china-kembangkan-9-vaksin-potensial-untuklawan-virus-corona

[26] Gunawan D., "Director of LBM Eijkman Explains the Reason for Indonesia to Make a COVID-19 Vaccine (Direktur LBM Eijkman Beberkan Alasan RI Bikin Vaksin COVID-19), Detikcom, 25 Maret 2020. [Online]. Available: https://news.detik.com/berita/d-4952190/direktur-lbm-eijkman-beberkan-alasan-ri-bikin-vaksin-COVID-19

[27] Afifah MN., When is the best time to bask in the sun for good health (Kapan Waktu Terbaik Berjemur di Bawah Sinar Matahari untuk Kesehatan?), Kompas, 07 Maret 2020. [Online]. Available: https://health.kompas.com/read/2020/03/07/073000968/kapan-waktu-terbaik-berjemur-di-bawah-sinar-matahariuntuk-kesehatan-?page=all

[28] World Health Organization, "Coronavirus disease (COVID-19) advice for the public: Myth busters Coronavirus disease (COVID-19) advice for the public: Myth busters", World Health Organization, cited 6 May 2020. [Online]. Available: https://www.who.int/emergencies/diseases/novel-coronavirus-2019/advice-for-public/myth-busters

[29] Velarosdela Rn., Increase Immunity, Polda Metro Jaya Prisoners Bask Every Morning (Tingkatkan Imunitas, Tahanan Polda Metro Jaya Berjemur Setiap Pagi), Kompas, 26 Maret 2020. [Online]. Available: https://megapolitan.kompas.com/read/2020/03/26/14385281/tingkatkan-imunitas-tahanan-polda-metro-jayaberjemur-setiap-pagi

[30] Wuqi Q., et al., "Risk communication and public health. Global Journal Of Medicine And Public Health," Global Journal of Medicine And Public Health., vol. 5, no. 4, pp. 1-11, 2016. 